ISSN 0103-5150

Fisioter. Mov., Curitiba, v. 29, n. 1, p. 131-36, Jan./Mar. 2016

Licenciado sob uma Licença Creative Commons

DOI: http://dx.doi.org.10.1590/0103-5150.029.001.A014

(c)

\title{
Evaluation of gross motor function before and after virtual reality application
}

\author{
Avaliação da motricidade grossa em indivíduos com paralisia \\ cerebral pré e pós aplicação da realidade virtual
}

\author{
Luiza da Silva Pereira Tannus, Danieli Isabel Romanovitch Ribas*
}

Centro Universitário Autônomo do Brasil (UNIBRASIL), Curitiba, PR, Brazil

\begin{abstract}
Introduction: Recently virtual reality has been aggregated to the therapeutic possibilities for patients who need functionality gains, such as individuals with cerebral palsy (CP). Aim: to evaluate the effects of virtual reality on the gross motor function of individuals with CP. Methods: longitudinal study, realized in a special education school, with five individuals with CP (7.4 years of age \pm 1.14 ) of both sexes, evaluated using the B, D and $\mathrm{E}$ dimensions of the GMFM 88, before and after the application of three Wii Fit Plus ${ }^{\circledR}$ console games: Hula Hoop, Slide Penguin and Soccer Heading. These games were applied for four minutes per game, at the beginner level, twice a week, for twelve consecutives weeks. The normality of the sample was evaluated through the Shapiro-Wilk's test. The results obtained before and after the Wii Fit ${ }^{\circledR}$ application were compared using descriptive statistics. Results: all the individuals obtained improvements in the dimensions evaluated after the virtual reality application, with a 5.14\% general improvement, varying between $1.9 \%$ and $9.6 \%$. The standing (D) and walking, running and jumping (E) dimensions were the dimensions which obtained higher improvement percentages. Conclusion: considering the study limitations, the results obtained suggest that virtual reality can promote benefits in the gross motor function of individuals with cerebral palsy.
\end{abstract}

Keywords: Cerebral Palsy. Motor Skills. Vídeo Games.

\footnotetext{
* LSPT: grad, e-mail: lulizasp@hotmail.com

DIRR: PhD, e-mail: danieliribas@yahoo.com.br
} 
Resumo

Introdução: Recentemente a realidade virtual vem sendo agregada às possibilidades terapêticas para pacientes que necessitam de ganhos de funcionalidade, tais como, os indivíduos com paralisia cerebral (PC). Objetivo: avaliar os efeitos da realidade virtual na função motora grossa de indivíduos com paralisia cerebral. Metodologia: estudo longitudinal, realizado em uma escola de educação especial com cinco indivíduos com PC $(7,4$ anos $\pm 1,14)$ de ambos os gêneros, avaliados por meio da GMFM 88, nas suas dimensões $B, D$ e E, antes e após a aplicação de três jogos do console Wii Fit plus ${ }^{\circledR}$, hula hoop, slide pinguim e soccer heading. Todos os jogos foram aplicados no nível iniciante, por doze semanas consecutivas, duas vezes na semana, sendo cada jogo aplicado por quatro minutos. A normalidade da amostra foi avaliada por meio do teste Shapiro Wilke. Os resultados obtidos pré e pós aplicação do vídeo game Wii Fit ${ }^{\circledR}$ foram comparados por meio da estatística descritiva. Resultados: todos os indivíduos obtiveram melhora nas dimensões avaliadas após a aplicação da realidade virtual, sendo esta de 5,14\%, com variação entre 1,9\% e 9,6\%. As dimensões em pé (D) e caminhando, correndo e saltando (E), foram as dimensões que obtiveram maior porcentagem de melhora. Conclusão: considerando-se as limitações deste estudo, os resultados obtidos sugerem que a realidade virtual pode promover benefícios na motricidade grossa de indivíduos com paralisia cerebral (PC).

Palavras-chave: Paralisia Cerebral. Destreza Motora. Jogos de Video.

\section{Introduction}

The changes in an individual's level of functioning over time are described as the development process. This is part of the motor development, effected by the interaction between the task requirements, the biology of the individual and the environmental conditions (1). The first six years of life are crucial for motor development (2), therefore, some diseases that act at this stage can compromise it.

Known as one of the most common causes of disability in early childhood (3), cerebral palsy, also called chronic non-progressive encephalopathy of childhood (4), is characterized by postural deficits and changes in muscle tone and in the execution of movements, which appear early in a child's life.

Cerebral palsy also has a non-degenerative character (5), generally resulting from damage or dysfunction in the Central Nervous System (CNS) during development (6), which typically originates in the pre-, peri- or immediate post-natal period. The etiology is varied, possibly being genetic, inflammatory, infectious, anoxic, traumatic or metabolic (3).

Approximately $75 \%$ of affected individuals present exacerbation of the tendon reflexes, spasticity in the appendicular region and resistance to rapid passive movement, with axial hypotonia being found in some individuals $(6,7)$. These compromises culminate in changes in postural reactions, which are the stable base for performing movements against gravity.
The development of children with cerebral palsy occurs at a slower pace and with abnormal progress when compared to other children, resulting in achieving motor milestones later or not at all (8).

Children with cerebral palsy, regardless of their classification based on the type of muscle tone (spastic, dyskinetic, ataxic), distribution of the involvement in the body (diplegic, hemiplegic and quadriplegic) and level of independence of the individual (6), will present difficulty in the acquisition of neuroevolutive patterns of human development, among which is the gait. In cases where the gait develops, this is generally late, between 18 and 24 months (9). For these children, gait training is important to stimulate the automation of steps with proper biomechanical alignment and the adjustment of speed and coordination, thus improving the quality of independent walking (10).

The overall development of the child is strongly influenced by motor activity. Self-awareness and awareness of the outside world develop through motor exploration and the skills related to it, this being an important auxiliary means for the achievement of independence (11). Psychomotor activities are recommended by many authors for the promotion of the cognitive, motor and affective development of children, especially when they take place in a playful environment (12).

In recent years, new resources using virtual reality have been included as therapeutic possibilities for 
patients that need to correct balance and posture, improve mobility and increase functionality and motivation, as required by patients with cerebral palsy. One of these resources is the video game $W_{i i}{ }^{\circledR}$, cited in some studies to be beneficial for the aforementioned therapeutic goals (13).

Considering the possible deficiencies of children with cerebral palsy and the potential benefits of the resources of virtual reality in the treatment of these children, as demonstrated in other scientific studies, this study aimed to evaluate the effects of virtual reality on the gross motor function of individuals with cerebral palsy, in relation to sitting, standing and walking, running and jumping.

\section{Methodology}

This longitudinal study was performed in a special education school in the city of Curitiba, state of Parana. It was approved by the Research Ethics Committee of the Integrated Faculties of Brazil, under authorization No. 043/2009, and complied with the National Health Council Resolution 466/12 for research involving human subjects.

Inclusion criteria were individuals of both genders, aged from six to ten years, with permission from the person legally responsible to participate in the study after reading and signing the informed consent form (ICF). Exclusion criteria were individuals with moderate and severe mental retardation, hearing or visual impairments, and those unable to understand simple verbal commands, to remain standing or to walk without assistance. Children were also excluded that, in the course of the study field process, had two or more absences registered.

Initially, the sample consisted of ten individuals with chronic non-progressive encephalopathy of childhood, all enrolled in the previously mentioned institution. However, due to absences, the final sample was composed of five individuals.

The motor skills of those selected were evaluated using the GMFM 88 (Gross Motor Function Measure) scale, translated into Portuguese (Medida da Função Motora Grossa), which provides a quantitative evaluation of static and dynamic motor aspects (4).

Through this scale it is possible to evaluate, by means of observation, the dimensions A (lying down and rolling - 4 items), B (sitting - 15 items), C (crawling and kneeling - 10 items), D (standing - 13 items) and E (walking, running and jumping - 24 items). For each of the items of the five dimensions evaluated, grades $0-3$ are established, with the score 0 attributed to inactivity in the proposed activity, grade 1 attributed to the beginning of the requested action, however, with less than $10 \%$ performance of the activity, grade 2 assigned to the partial performance of the task (greater than or equal to $10 \%$, but less than $100 \%$ ), and finally grade 3 attributed to the complete performance of the action (14). In the present study the dimensions B, D and E were considered.

After recording the scores for each item, the scores were summed to obtain the total value for the dimension and subsequently converted into percentages. The higher the value obtained in each dimension, the better the functional capacity of the evaluated individual.

The GMFM 88 was applied at two times: before and after the application of three games of the wii fit plus console ${ }^{\circledR}$ : Hula Hoop, Slide Penguin and Soccer Heading. The three games are run on a platform (balance board) and in the Hula Hoop game the player performs circulatory movements with the hip, this being captured by the sensor and shown on the video screen as an avatar with a hula hoop around the waist. Through the oscillations on the platform, the avatar moves and prevents the hoop falling to the ground. In the Slide Penguin game, it is necessary for the individual to constantly transfer the body weight between the legs, so that the penguin avatar can catch fish without falling into the water and stay on top of the iceberg. In the Soccer Heading game, the player must be aware and position him/ herself according to where the balls thrown by the virtual players will go, and thus try to head them towards the goal net. These movements stimulate the oscillation of the support base of the individuals and movements of the trunk and head, stimulating balance and postural control. These games were selected after a pilot study with the sample, when instability in the standing posture was verified, as well as constant adjustments of the movement and balance that the games provided. The games were applied at the beginner level, for twelve consecutive weeks, twice a week, with each game applied for four minutes.

The Ashworth scale was used for the evaluation of the spasticity in the sample and the Shapiro-Wilk 
test to verify the normality. The results obtained before and after applying the Wii Fit ${ }^{\circledR}$ video game were compared using descriptive statistics.

\section{Results}

The characterization of the individuals selected for the study is presented in Table 1 .

Table 1 - Characterization of the sample $(n=5)$ in relation to chronological age, gender, type and topography of cerebral palsy and degree of muscle tone according to the Ashworth Scale

\begin{tabular}{lc}
\hline \multicolumn{1}{c}{ Characteristics } & Values \\
\hline $\begin{array}{l}\text { Chronological age (mean)/ } \\
\text { standard deviation } \\
\text { Gender }\end{array}$ & 7.4 years \pm 1.14 \\
Type of Cerebral Palsy & 2 female / 3 male \\
Topography & 3 spastic/2 ataxic \\
Ashworth Scale & 2 diplegic/1 hemiplegic \\
Weight & $2 / 3$ \\
Height & $71.23 \pm 10.67$ \\
\hline
\end{tabular}

The percentages obtained in relation to the dimensions, sitting, standing, walking, running and jumping, and the total percentage for each individual, obtained using the GMFM 88 scale, before and after the application of the virtual reality games, are presented in Table 2.
By analyzing the results in Table 2 it can be seen that all the individuals presented improvements in the dimensions evaluated after the application of the virtual reality games, with a mean improvement of $5.14 \%$, ranging between $1.9 \%$ and $9.6 \%$.

It was observed that the individuals, in general, presented the best initial values in the sitting ability, while the initial values were the lowest in the walking, running and jumping abilities. The latter was the dimension that obtained the highest improvement percentage, with the emphasis on individuals 2 and 4 , who obtained $12.9 \%$ and $7.6 \%$ increase in the standing dimension and $12.5 \%$ and $8.3 \%$ increase in the walking, running and jumping dimension respectively.

\section{Discussion}

The results of this study demonstrate improvement in the sitting, standing and walking, running and jumping dimensions for all individuals when comparing the scores in the GMFM 88 scale for the initial and final periods of the study, regardless of the type of muscle tone presented by the sample. These results are consistent with other studies that also used virtual reality in the treatment of children with diagnosis of $\mathrm{CP}(15,16,17)$.

The motor gains made by the study sample can be explained by factors such as motor learning, creating new sensory engrams, visual feedback and body adjustments, provided by the virtual reality games.

Table 2 - Results obtained by calculating the GMFM scale score before and after application of the exercises with the Wii ${ }^{\circledR}$ video game

\begin{tabular}{lcccc}
\hline & Sitting & Standing & Walking, running and & Total \\
& & & jumping & \\
\hline Individual $\mathbf{1}$ & Pre / post & Pre / post & Pre / post & Pre / post \\
& $83.3 \% / 86.6 \%$ & $25.6 \% / 28.2 \%$ & $34.7 \% / 36.1 \%$ & $47.8 \% / 50.3 \%$ \\
Individual 2 & $(3.3 \%)$ & $(2.6 \%)$ & $(1.4 \%)$ & $(2.5 \%)$ \\
& $70 \% / 73.3 \%$ & $43.5 \% / 56.4 \%$ & $43 \% / 55.5 \%$ & $52.1 \% / 61.7 \%$ \\
Individual 3 & $(3.3 \%)$ & $(12.9 \%)$ & $(12.5 \%)$ & $(9.6 \%)$ \\
& $91.6 \% / 96.6 \%$ & $76.9 \% / 82.2 \%$ & $75 \% / 77.7 \%$ & $81.1 \% / 85.5 \%$ \\
Individual 4 & $(5 \%)$ & $(5.3 \%)$ & $(2.7 \%)$ & $(4.4 \%)$ \\
& $95 \% / 100 \%$ & $87.2 \% / 94.8 \%$ & $79.2 \% / 87.5 \%$ & $86.8 \% / 94.1 \%$ \\
Individual 5 & $(5 \%)$ & $(7.6 \%)$ & $(8.3 \%)$ & $(7.3 \%)$ \\
& $91.6 \% / 93.3 \%$ & $92.3 \% / 92.3 \%$ & $65.3 \% / 69.4 \%$ & $83.1 \% / 85 \%$ \\
& $(1.7 \%)$ & $(0.0 \%)$ & $(4.1 \%)$ & $(1.9 \%)$ \\
\hline
\end{tabular}


To carry out the games proposed, the individuals challenged their previously acquired movement capacity, being required to constantly change the standing posture through their body adjustments on the platform, in order to control the stimulation provided by the environment $(17,18)$. This favored motor learning and the creation of new sensory engrams, realigning the motor pattern, which once learned is stored and can be used every time the individual is subjected to similar situations (19). According to Chen et al. (2007), children with CP gradually find more efficient ways to achieve their goals in the games, moving themselves in a faster, smoother and more erect way.

To carry out the proposed activities, it was necessary for the individuals to seek stability (static balance), controlled mobility (weight transfer) and motor skills, which depend on normal postural tone, on the variety of interaction between opposing muscle forces with reciprocal innervation action, and on the variety of posture and movement patterns $(7,17)$, which were shown to change in the individual with $\mathrm{CP}$. This situation encouraged the nervous system to plastically adapt to seek reorganization strategies, resulting in positive behavioral changes and, consequently, improved functional abilities.

Visual feedback allowed motor control and learning (21), as it provided self-perception and immediate correction of the posture and orientation in the space (13). For Matos et al. (2010) vision plays a proprioceptive role in controlling the posture, in both adults and children, and, to acquire balance, with the individual using this sense to adapt muscle activity, combining vestibular and proprioceptive stimuli with the information provided by the environment.

Situations of a psychological nature, such as confidence, security, motivation and dispersion, must also be considered when analyzing the results obtained. Trust, confidence and motivation to perform activities positively influenced the study results. According to Menger (2010), learning is a process that involves bonds between the teacher and the learner, and as this bond is strengthened trust and confidence occur, which favors the motor act and the learning. The motivation of the child directly affects information processing and, consequently, its retention is acquired through practice, providing better motor control in the performance of the task $(18,24,25)$.

Conversely, situations of extreme motivation, may have negatively contributed to the acquisition of the results, since this situation may favor the change in muscle tone. According to Marsura et al. (2012), children with change in muscle tone may present poor balance, resulting in lower postural stability, difficulty in initiating movement and diminished responsiveness and speed of movement. Another factor that may have influenced the results of the present study was the need for some individuals to use support at certain times for the performance of the proposed games, decreasing the creation of new motor strategies and range of adjustments offered by the Wii.

Even with these possible biases, prior to the application of the proposed games precautions were taken to ensure the internal validity of the study.

\section{Conclusion}

Considering the limitations of this study, which are mainly related to the sample (number of subjects), the results suggest that virtual reality can promote benefits in the gross motor function of individuals with cerebral palsy (CP). Thus, it appears that virtual reality can be used as a rehabilitation tool for people who have motor changes due to CP. However, new studies using the technology should be carried out, considering a greater sample size, the length of application of the games, their schedule and the evaluation of the game according to the profile of the patient.

\section{References}

1. Gallahue DL, Ozmum JC. Compreendendo o desenvolvimento motor: bebês, crianças, adolescentes e adultos. São Paulo: Forte, 2003.

2. Caetano MJD, Silveira CRA, Gobbi LTB. Desenvolvimento motor de pré-escolares no intervalo de 13 meses. Revista Brasileira de Ciantropometria e Desempenho Humano. Rio Claro, 2005;7(2):05-13.

3. Zanini G, Cemin NF, Peralles SN. Paralisia Cerebral: causas e prevalências. Fisioter Mov. 2009; 22(3):375-81.

4. Mélo TR. Escalas de Avaliação do Desenvolvimento e Habilidades Motoras: AIMS, PEDI, GMFM e GMFCS in: Fisioterapia em neuropediatria. Editora Omnipax, 2011. Disponível em: http://omnipax.com.br/ livros/2011/ FNP/ FNP-cap1.pdf. 
5. Leite JM, Prado FG. Paralisia cerebral: aspectos fisioterapêuticos e clínicos. Revista Neurociências, 2004; 12(1): 41-5.

6. Chagas PSC, Defilipo EC, Lemos RA, Mancini MC, Frônio JS, Carvalho RM. Classificação da função motora e do desempenho funcional de crianças com paralisia cerebral. Rev Bras Fisioter. São Carlos, 2008; 12(5): 409-16.

7. Forti-Bellani CD, Castilho-Weinert LV. Desenvolvimento Motor Típico, Desenvolvimento Motor Atípico e Correlações na Paralisia Cerebral. In: Fisioterapia em neuropediatria. Editora Omnipax, 2011. Disponível em: http://omnipax.com.br/livros/2011/FNP/FNPcap1.pdf.

8. Assis-Madeira EA, Carvalho SG. Paralisia cerebral e fatores de risco ao desenvolvimento motor: uma revisão teórica. Cadernos de Pós-Graduação em Distúrbios do Desenvolvimento, São Paulo, 2009; 9(1):142-63.

9. Marques J.S. et al . Maturação da marcha em crianças com paralisia cerebral: Um estudo piloto. Motri., Vila Real, 2011; 7(2).

10. Junior IPC, Toffol WC, Junior JCB, Fonseca GP. Desempenho da marcha em indivíduos com paralisia cerebral após aplicação de toxina botulínica, submetidos à fisioterapia: revisão sistemática. Revista Movimenta. 2009;2(4): 144-53.

11. Rosa Neto F. Manual de Avaliação Motora. Porto Alegre: Artmed, 2002.

12. Arruda KMF, Silva EAAS. Desenvolvimento Motor na Educação Infantil através da ludicidade. Estágio Supervisionado em Educação Infantil do curso de Educação Física do UNIVAG: Várzea Grande, 2010.

13. Schiavinato AM, Bandan CB, Melatto L, Lima LS. Influência do Wii Fit no equilíbrio de pacientes com disfunção cerebelar: estudo de caso. J Health Sci Inst.2009; 28 (1):50-2.

14. Nunes LCBG. Tradução e validação de instrumentos de avaliação motora e de qualidade de vida em paralisia cerebral [Thesis].Campinas,SP:Universidade Estadual de Campinas, Faculdade de Engenharia Elétrica e de Computação, 2008.

15. Abdalla TCR, Prudente COM, Ribeiro MFM, SOUZA JS. Análise da evolução do equilíbrio em pé de crianças com paralisia cerebral submetidas a reabilitação virtual, terapia aquática e fisioterapia tradicional. Revista Movimenta, 2010;3(4).
16. Barcala L, Colella F, Araújo MC, Salgado ASI. Análise do equilíbrio em pacientes hemiparéticos após o treino com o programa Wii Fit. Fisioterapia e Movimento., Curitiba, 2011; 24(2):337-43.

17. Deutsch JE, Borbely M, Filler J, Huhn K, Guarrera-Bolwby P. Use a low-cost, commercially, available gaming console (Wii) for rehabilitation of an adolescent with cerebral palsy. Physical Therapy. 2008;88(10):1196-207.

18. Monteiro CBM, Jakabi CM, Palma GCS, Torriani-Pasin C, Meira CMJ. Aprendizagem motora em crianças com paralisia cerebral. Rev. bras. crescimento desenvolv. hum. 2010;20(2):250-62.

19. Fox EL, Foss ML. Bases fisiológicas da Educação Física e do Desporto. 4⿳a a edição. São Paulo: Editora Guanabara Koogan. 1991.

20. Chen YP, Kang LJ, Chuang TY, Doong JL, Lee SJ, Tsai MW, et al. Use of virtual reality to improve upper-extremity control in children with cerebral palsy: A single-subject design. Physical Therapy, 2007; 87(11):1441-57.

21. Souza FH. Uma revisão bibliográfica sobre a utilização do Nintendo ${ }^{\circledR}$ Wii como instrumento terapêutico e seus fatores de risco. Revista Espaço Acadêmico, 2011; 11(123).

22. Matos MR, Matos CPG, Oliveira CS. Equilíbrio estático da criança com baixa visão por meio de parâmetro estabiliométrico. Fisioter Mov. 2010; 23(3):361-9.

23. Menger EMC. A afetividade nas práticas pedagógicas. Universidade Federal do Rio Grande do Sul, 2010.

24. Marchett PH, Belmiro WO; Jogos Eletrônicos Interativos "Exergaming": uma breve revisão sobre suas aplicações na Educação Física. Pernambuco, Universidade Federal de Pernambuco, 2011.

25. Okimoto AM, Bundy A, Hanzlik J. Playfulness in Children With and Without Disability: Measurement and Intervention. Am J Occup Ther. 2000;34(1).

26. Marsura A, Santos MP, Silvia MA, Mendes TCA, Leite A, Silva AM. A interferência da alteração de tônus sobre a reabilitação fisioterapêutica após lesões neurológicas. Saúde em foco, 2012; 7-11.

Recebido: 19/11/2013 Received: 11/19/2013

Aprovado: $10 / 08 / 2015$ Approved: 08/10/2015 